\title{
AL-ZARNUJI'S CHARACTER CONCEPT IN STRENGTHENING CHARACTER EDUCATION IN INDONESIA
}

\author{
Djeprin E. Hulawa \\ Universitas Islam Negeri Sultan Syarif Kasim Riau \\ Jl. H. R. Soebrantas Panam Km. 15 No. 155, Tuah Madani, Tampan, Pekanbaru, Indonesia, 28293 \\ Email: djeprin.ehulawa@uin-suska.ac.id
}

Received: 04, 2018. Accepted: 01, 2019. Published: 01, 2019.

\begin{abstract}
This study aims to find the relevance and contextualization of the thoughts of al-Zarnuji's character in the present context especially in relation to strengthening character education in Indonesia. The research used the incorporative approach and descriptive, heuristic and hermeneutic methods. The analysis technique used analytical content. The study found that there was relevance in the concept of al-Zarnuji's character to the concept of strengthening character education in Indonesia, where both of them made aspects of noble character and morality as the pillars and main souls of humans in nationbuilding. Although in a different socio-cultural context, the concept of al-Zarnuji's character and the concept of character education in Indonesia both go in the same direction, namely the effort to establish positive characters for students through education.
\end{abstract}

Keywords: Contextualization, Character Building, Positive Character

\begin{abstract}
ABSTRAK
Penelitian ini bertujuan menemukan relevansi dan kontekstualisasi pemikiran karakter al-Zarnuji dalam konteks kekinian terutama dalam bubungannya dengan penguatan pendidikan karakter di Indonesia. Penelitian ini menggunakan pendekatan inkorporatif dan metode deskriptif, idealisasi, heuristika dan hermeneutika. Teknik. analisisnya menggunakan content analisis. Hasil penelitian menunjukan adanya relevansi konsep karakter al-Zarnuji dengan konsep penguatan pendidikan karakter di Indonesia di mana, keduanya menjadikan aspek. budi pekerti dan akblak mulia sebagai pilar dan rub utama manusia dalam pembangunan bangsa. Meskipun dalam sosio-kultural yang berbeda, antara konsep karakter al-Zarnuji dan konsep pendidikan karakter di Indonesia keduanya menuju arah yang sama, yaitu upaya pembentukan karakter positif bagi peserta didik melalui jalul pendidikan.
\end{abstract}

Kata Kunci: Kontekstualisasi, Membangun Karakter, Karakter Positif

\section{INTRODUCTION}

National character development was an important agenda since the beginning of Indonesian independence and was declared the main goal of education at that time. Law Number 4 Year 1950 concerning Fundamentals of Education and Teaching in Schools, Article 3, or "Law Number 4 Year 1950 concerning Basic Education and Teaching in Schools is regulated in Article 3", emphasizing that the purpose of education and teaching is to establish capable citizens and democratic citizens and are responsible for the welfare of citizens and homeland Article 4 emphasizes that education and teaching are based on the principles outlined in the Pancasila and the Constitution of the Republic of Indonesia (Penders, 1968).

Apparently, the concept of character education carried by each character even though in the context of time and different cultural settings, the central idea can be united in one common theme, namely how to instill attitudes, identity and morality as the core character of the community that is latent and identity nationality in the global arena and face the everchanging flow of times. In the context of contributing to strengthening character education in Indonesia, the concept of the character of al-Zarnuji is worth reviewing. 
Admittedly, the concept of education of the character of al-Zarnuji has been widely studied in scientific research in the form of theses, dissertations, and articles in various scientific journals. Each writing has its own peculiarities both in terms of content, methodology, and object of study.

Maslani, Suntiah, Yasniwarti, \& Nurulhaq (2017) described the basic concepts of alZarnuji both about learning material, strategy, ethics, process and its contribution in the achievement of learning ethics of students in Kebon Jambu Islamic Boarding School, Buntet and Bendakerep Cirebon with the results of the study showing the application of Ta'lim alMuta'allim as a primary source of ethics does not significantly contribute to the ethical development of santri in the pesantren because of its textual and non-contextual understanding. While the research conducted by the author in this article also concludes the same thing. The difference, what is called non-contextual is only a small part of al-Zarnuji's thinking, especially in the article Glorifying Science and Ulama and behavior that must be carried out or abandoned by the claimants of knowledge in his life.

Huda \& Jasmi (2016) examined al-Zanuji's concept of knowledge and didn't mention the slightest issue of character. The researcher concludes that the category of knowledge in AlZarnuji's perspective is divided into two main categories namely fardhu kifäyah and fardhu 'ayn which is guided by Islamic religious values. The focus of the study of Huda \& Jasmi (2016) is very different from the focus of the study of the author.

Shofwan (2017) focused his study on learning methods. But because the basic concept comes from the same source (al-Zarnuji), then inevitably this research must finally reveal almost every article in the book Ta'lim al-Muta'allim including problems of sustenance and longevity. If compared to the author, this study does not specifically refer to a character as its central object (Shofwan, 2017). It is clear that this study is different from previous researchers.

Huda \& Kartanegara (2015) focused more on studying the noble character and actualization of Islamic values as an important effort to build and instill Islamic ideology as a way of life and probing Islamic patterns as forming character values as existing in Islamic institutions and in several Muslim countries.

The research which was conducted by Masamah \& Zamhari (2017) departs from character phenomena as the central issue of the book Ta'lim al-Muta'allim and then connects its contextualization with the world of modern education. In particular, this discussion finally leads to the conclusion that character education in Ta'lim al-Muta'allim is a process of character internalization and ethics of being a student that includes mental development based on the concept of faith. This research also formulated three important methods in the development of character which included body and soul, namely ilqa al-nasibah (advisor) and method of affection; The mudzäkarah, munädharah, and muthärahah are methods for mental and spiritual development. The three methods were then used to examine the relevance of education at this time by concluding that this method is still relevant for use in education today. Objectively, Zamhari's study did not touch on the issue investigated by the present study.

The research of Thohir, C, \& Dardiri (2017) focused more on the analysis of the book Ta'lim al-Muta'allim and compared to some books of Plato's philosophical idealism. Furthermore, it compared with documents from various sources about Platonidealism which ended in the conclusion that there were some similarities and differences between Sheikh alZarnuji's thoughts and Plato's. For example, the similarity between the two is the concept of metaphysics in Ta'lim al-muta 'allim called ma'rifatullăh, while the concepts included in Plato are called idealistic concepts of macrocosm and microcosm. That similarity has an impact on the shared educational goals of al-Zarnuji, students and revitalizes the direction, becomes an individual for himself, to achieve goodness and unity with God. The difference is mainly expressed in the concepts of metaphysical specific aspects in each review. For example, al- 
Zarnuji says that reality comes from God, while idealism states that reality can be explored in God through contemplation or ideas or reasons.

Hafidzah (2014) conducted a comparative study of the book Ta'lim al-Muta'allim Thariq at-Ta'allum by al-Zarnuji and the book Adãb al-'Alim wa al-Muta'alim by Hasyim Asy'ari from a historical aspect, systematic writing, content, and position of the two books among boarding schools. As a classical text study and authenticity consideration of works, which is used by researchers is a classic text stored at the Leiden University Library, Netherlands. From the results of the comparative study, she concluded some similarities and differences. The two complements each other, especially the work of Hasyim Asy'ari which was written far after the work of al-Zarnuji. Looking at the nature of the study, Hafidzah's research and author's research are very different.

Setiawan (2014) said that al-Zarnuji and al-Ghazali contribute to building national character. According to researchers, al-Ghazali's thinking was positively and responsively absorbed by the Indonesian government to build a national character that was widely implemented in the national curriculum based on local wisdom and Islamic values. While AlZarnuji put the character of Islam as a moral behavior of students consisting of physical and mental values in education. What distinguishes this study from previous studies is that the research does not thoroughly examine the technical issues of students' daily life patterns as a habit of positive character as reviewed by the authors in this article.

Syamsirin (2010) focused on the study of ethics as the ultimate goal of education, but the study does not focus on the basic ideas of ethics as the subject of studies actually penetrating various concepts of al-Zarnuji in the book Ta'lim al-Muta'allim such as learning methods, patterns of relationships between teachers and students, and the ideal curriculum. Of course, the focus of research studies is different from the focus of studies conducted by the present study.

Pimay (1999) examined the comparison of the concepts of educators al-Ghazali and alZarnuji, but in reality, the study in this thesis extends to various technical issues such as the rights and obligations of students and the concept of ethics of teachers and students. Pimay's thesis does not specifically address character education especially in relation to character-based curricula in Indonesia as described by the authors in this article.

What is closer to this study is a book by Chotimah (2018). The book with the title "Relevance of the Character Education Concept according to Sheikh Burhanuddin al-Zarnuji in the Book Ta'lim al-Muta'allim with the 2013 Curriculum." This book emphasizes the importance of strengthening character education for students from the perspective of facing globalization. The focus of the research in this book is the concept of character education according to al-Zarnuji in the book Ta'lim al-Muta'allim and the relevance of the concept of character education in the 2013 curriculum. Significantly different between Husnul Chotimah's study and the author is on the side of implementing the concept of a character, where the author technically presents all the articles in the book Ta'lim al-Muta'allim then reviews the actualization and relevance of the concept in modern life today. Even though both studies have similarities due to the similarity of characters, but both emphases are different. Except, there are still many other figures and researchers who study al-Zarnuji in various perspectives but none of them are exactly the same as the present study.

\section{METHOD}

The study used is incorporative approach by exploring ideas from the study of texts by al-Zarnuji. It is seen from various character thoughts released from the flow system and then integrated with the character education system in Indonesia. In revealing the character's thoughts, the author uses descriptive, idealization, heuristic and hermeneutic methods. The 
analysis technique used is analytical content which is to draw conclusions in an effort to find the characteristics of the messages it contains carried out objectively and systematically so that the thinking is contextual and relevant for strengthening the character of education in Indonesia.

\section{RESULTS AND DISCUSSION An Overview of the Book Ta'lim al-Muta'allim}

In general, the book Ta'lim al-Muta'allim is directed by Shaykh Ibrahim bin Isma'il, about 48 pages thick containing Muqaddimah and 13 chapters. The Brief explanation of each chapter is as follows:

Chapter 1. The nature of science and its virtue. Al-Zarnuji explains the urgency of understanding and prioritizing knowledge. Itself requires knowledge that the claimant of knowledge is not always in ignorance. The law of knowledge for men and women is fardhu'ain. The Prophet said that "studying is an obligation for every Muslim" (Narrated by Ibnu Abdil Bari). However, human beings are not required to learn all kinds of knowledge but are only required to learn all science (knowledge that is always needed in supporting the life of religion). Humans are also required to study the necessary science at all times and with regard to their obligations, such as prayer, fasting, and pilgrimage (Al-Zarnuzi, n.d.).

Humans are also required to study the sciences related to the profession and his career. Someone who is busy with his job duties (for example trading), they must know how to avoid haram. Also required for human learning ahwäl al-qalb, such as tawakkal, ridla and so on. Man must be noble, therefore he is obliged to learn good and bad morals and how to stay away from it. In addition to the obligatory study of compulsory science, al-Zarnuji also told humans to study the sciences whose usefulness only in certain times, the law fardbu kifäyah like the science of shalat alms, the science of medicine, the science of astronomy and so forth. While studying science that has no benefit or even harm, the law is haram like necromancy. On another occasion, he is very concerned about studying Fiqh because it is the main guide to the good, the saving fortress of all difficulties (Al-Zarnuzi, n.d.).

Chapter 2. Intention to seek knowledge. Al-Zarnuji reminds us that the right intention in seeking knowledge is to seek the pleasure of Allah, to gain happiness in the world and the hereafter, to fight against ignorance on self and others, to develop and preserve the teachings of Islam, and to be grateful for the blessings of Allah. In connection with that, al-Zarnuji reminded that every claimant of science is not to mistakenly determine the intention in learning, such as learning that is intended to seek influence, obtain worldly pleasures or honor and a certain position.

Chapter 3. Choosing teachers, knowledge, friends, and attitude in learning. Learners should choose the best science and knowledge needed in their religious life both now and in the future. They must prioritize the science of monotheism and ma'rifat and his proposition. In choosing educators, they should perform more wara', pious, relieved, and patient, in addition to purifying their intention just for Allah in carrying out its activities (Al-Zarnuzi, n.d.). They also must be patient and steadfast in learning to educators who have been selected and patient in the face of various trials. They should choose a diligent, honest, and easy-to-understand friend, avoiding lazy, talkative, unemployed, vandalistic and libelous. Al-Zarnuji also encourages learners to put forward deliberation in all things faced. Since science is a very important matter, but it is also difficult, the deliberation here becomes more important and necessitates its implementation (Al-Zarnuzi, n.d.). Yunus (1990) said: "The teacher's relationship with the students should be like the father's relationship with his children. $\mathrm{He}$ must know the circumstances of his disciples and the tendencies of his heart, where his weaknesses and how to cure them". 
Chapter 4. Respect for science and scholars. Learners should respect knowledge, ulama, and educators. If they hurt the educators, the blessing of their knowledge can be closed. How to honor educators can be performed in this way; not walking in front of him, not occupying his seat, not starting to speak except for his permission, not speaking in front of him, not asking something when his educator is tired, not sitting too close to him while studying unless forced to. In principle, learners have to do the things that make educators willing and happy (Al-Zarnuzi, n.d.).

Respect for science implies respecting for educators and their friends and glorifying the book. Related to the book, learners should not take the book except in holy circumstances, as well as in learning. They also should pay attention to the note, they always write neatly and clearly so that no regrets happening at a later day. To determine the science to be studied, they should consult with their educators, because educators are more experienced in learning. They always keep themselves from disgraceful morals, especially the attitude of arrogant (AlZarnuzi, n.d.).

The strive to achieve students' confidence, the teacher must pleasure them and save for their good and future. Let them believe that the teacher is wiser than them and he sees what they do not see. Give them a chance to try the good they will achieve if they ignore his instructions. Believe me, that by this way the teacher will be able to lead the disciples as best as possible" (Al-Zarnuzi, n.d.).

In line with this statement, Chomaidi (2005) revealed that: "The role of the teacher is not merely a value communicator, but also as an agent and a source of value that demands responsibility and capability in an effort to improve the quality of human development as a whole, both in the form of labiriyah and bathiniyah (physical and non- physical). This means that the characters are built, the character, the human person who has the quality of faith, the quality of work, the quality of life, the quality of mind, the feeling, and the will’.

Chapter 5. Serious, continuity and strong interest. Learners should be earnest in learning and able to repeat the lesson continuously in the early evening and at the end of the night between Maghrib and 'Isha and after the time, because those times are a time full of blessings (Al-Zarnuzi, n.d.). Al-Baghdādī \& 'Azazi (2001) added: "The best time to memorize is the time of dawn, at midday, then in the morning. Memorizing at night is better than daylight, and hunger is better than full stomach". They should have a strong interest and seriousness because these are the base of success.

The same thing is also said by Mahfud (2001) who states that "Interest is a concern that contains elements of feeling. Interest also determines an attitude that causes someone to be active in a job. In other words, interest can be the cause of an activity". Associated with the issue of jihad in the search for His pleasure, Allah says: "And those who strive for (seeking pleasure), We will indeed show them Ourpaths and verily Allah is with those who do good ". (Q.S. Al-Ankabut [29]: 69)

Chapter 6. The beginning of learning, intensity, and order. Learning should begin on Wednesday because that day Allah created nur (light), the unlucky day of unbelievers which means the day of blessings of the believers. For beginners, it should take a lesson that can be mastered well after it is repeated twice, then every day added piecemeal (principle of tadarruj and repetition), and so on. This is in accordance with Skinner's learning theory, as quoted by (Palmer-Cooper \& Assifa, 2003) that: "Learning materials should be submitted to students gradually taking into account the degree of difficulty and distance from one item to another. The students are encouraged to face the subject matter by having to answer the questions and confrontation with the quality of the answers because the machine will automatically evaluate the reaction. This program can find out whether the students are directed to different paths through the subject matter, depending on their answers so that students who give wrong 
answers can be returned to a more basic level, whereas consistent students who provide correct answers are allowed to leave the subject matter.

To make it easier for him to learn, students should familiarize themselves with buying the book and putting his allowance for it, because it will make it easier for him to study and study his lessons. Al-Zarnuji encourages learners to discuss because the benefits of discussion are greater than just repeating. With the discussion in addition to repeating also can increase knowledge. Discussions should be conducted with full awareness and avoid the things that bring negative consequences (Al-Zarnuzi, n.d.).

Chapter 7. Tawakkal. In learning, learners should be tawakkal to God and not tempted by the affairs of sustenance. Learners should not be troubled by worldly affairs, because anxiety cannot evade calamity, even harm the heart, mind, body and damage good deeds. Therefore, they should try to reduce worldly affairs (Al-Zarnuzi, n.d.). The Prophet said, "If you really put your trust in Allah, Allah will give you sustenance as birds get sustenance. The bird left in the morning in a state of hunger and returned in the afternoon in a state of fullness" (Albani, 310)

Chapter 8. The best time to learn. The learning period is from the cradle to the grave. The brilliant time to learn is the beginning of youth. Learning is done at dawn time and time between Maghrib and 'Isha. However, students should make the most of their time to learn. When you feel tired of studying science, you should learn another science. In line with the above statement, al-Khatib said: "The best time to memorize is the time of dawn, after that mid-afternoon, then the morning time. Memorizing at night is more useful than in the daytime, and memorizing when hungry is more useful than memorizing it in a state of fullness. The best place to memorize is in the room and any place that is far from the things that neglect" (Al-Kinani, 2009).

Chapter 9. Love and give advice. People who are pious should have a sense of affection, willing to give advice and do not envy. Learners should always try to adorn themselves with noble character. Thus, the person who hates will melt by itself. Do not get worse and get involved in hostilities, because it will only waste time and energy and unfold yourself. Islam strongly prohibits the above acts, as the word of Allah, which means: "O ye who believe, depart most of the prejudices (suspicion), for some of them are sins. And do not search for evil people and do not gossip about each other. Is there anyone of you who likes to 'eat the flesh' of his dead brother? Then surely you feel disgusted with him. And fear Allah SWT. Lo! Allah is the Most Receptive, the Merciful." (QS. AlHujurãt [49]: 12)

Chapter 10. Make the time. Learners should take advantage of all the opportunities to learn, to achieve excellence. How to use stationery at all times to record the scientific things that he obtained. He reminded that age is short and science is plentiful. Therefore, learners should not waste their time, but they should take advantage of night time and quiet moments. They should dare to suffer and able to subdue his desires (Al-Zarnuzi, n.d.).

Chapter 11. Wara' during the study period. What is meant by the nature of wara' is to keep oneself from the haram. During the time of learning, learners should apply wara', in order the knowledge will be more useful. Wara' includes keeping yourself from being too much eating, too much sleeping and too much talking about things that are not useful. Learners are reminded not to ignore the sunnah, reproduce the prayer and carry it out solemnly because it will help them achieve the success of their studies. Al-Zarnuji reminded that learners bring books to study and stationery to record all the knowledge they got. There is a saying that whoever there is no book in his pocket then there is no wisdom in his heart (Al-Zarnuzi, n.d.).

Chapter 12. The things that make someone easy to memorize and forget. With regard to memorization, each individual has different abilities. Some are easy to memorize, easy to forget too. Some are easy to memorize and always remember memorization, while others are 
hard to memorize and remember. Al-Zarnuji describes some of the powerful reasons for rote memorization and the causes of forgetting memorization. The causes of strong memorization are sincerity, continuity, prayer at night, eat less, and so forth (Al-Zarnuzi, n.d.).

Chapter 13. The Sustenance and age. Learners need to know things that can add sustenance, age and healthier, so it can devote all its ability to achieve what aspired. Among them, get up early and give lots of charity. The most powerful factor to obtain sustenance is the prayer with ta'dim, khusyu', perfect rukun, obligatory, sunnah and it's ordered. Among the factors causing added age is doing virtue, not hurt other people, hospitality, and other good deeds. Conversely, the factors that make a person's fortune are; too excessive in spending the treasure, lazing, procrastinating and easily dismiss a case (Al-Zarnuzi, n.d.).

From the elaboration of the entire chapter above, it can be understood that the construction of character education of al-Zarnuji is the implementation of the values of Qur'an and hadith as the standard of morality and the foundation for the implementation of teaching and learning activities. Because it stands on the right foundation (al-Qur'an and Hadith), the concept of character education of al-Zarnuji remains relevant and updated throughout the ages. To test the al-Zarnuji concept, it can be compared with the concept of character education below.

\section{Construction of Character Education}

The Configuration of character as a totality of psychological and socio-cultural processes can be grouped into: Spatial and emotional development, Intellectual development, Physical and Kinesthetic development, and Affective and Karsa (Affective and Creativity development). The four psychosocial processes (the heart, exercise, taste, and karsa) are holistically and coherently interconnected and complementary, which leads to the formation of character embodying the noble values (Kemendiknas, 2010).

If examined, the concept of character education is a refinement of the concept of Bloom's Taxonomy that characterizes the previous curriculum KTSP (Kurikulum Tingkat Satuan Pendidikan/Education Curriculum for Each Unit Level) and KBK (Kurikulum Berbasis Kompetensi/Competency-Based Curriculum). It highlights the mastery of students' cognitive, affective and psychomotor aspects and become the school's sole work to make it happen. While the concept of character education in the Curriculum 2013 is more directed to the efforts of character building and attainment of noble values are institutionalized in the soul of each learner and pursued achievement together.

In an effort to build the character of the students absolutely must be supported by a good environment. This is in line with Lickona's opinion that character does not work in a vacuum, it functions in a social environment. The environment usually emphasizes the desired moral value. He further explained that good character encompasses three things: moral knowledge, moral feeling, and moral behavior. Good characters are made up of knowing good, wanting good, and doing good habits of the mind, habits, and habits of action. Someone is said to have a good character if he not only knows about a good character but also manifested in his daily behavior (Lickona, 2009).

Based on the above explanation, it can be understood that learners in schools not only developed enough cognitive aspects, but also the moral and spiritual aspects. Changes in student behavior from time to time are one of the teachers' attention at school. Watson (2008) explains that students are viewed naturally as an empty whiteboard which will be established through strengthening to become productive learners and citizens. In a similar perspective, (Al-Ghazali, 2011) asserted, "The child is a mandate in the second hand of " the parents ". His clean heart is a precious gem, innocent and free of all kinds of carvings and images. Therefore, the task of education is not just to develop a child's cognitive aspects, but also his affective aspects. 
The form of character education that is implemented should be a comprehensive character education. Comprehensive character education is described in 11 principles as follows: (1) promoting core ethical values as the basis of good character; (2) defining character comprehensively by incorporating thinking, feeling, and behavior; (3) using a comprehensive, proactive and effective approach to character development; (4) creating school environmental awareness; (5) providing students with opportunities for moral action; (6) incorporating a meaningful and challenging academic curriculum and respect for all learners; (7) striving to encourage student motivation; (8) involving school staff in learning and responsible moral communities in character education and efforts to adhere to the same core values in guiding student education; (10) involving family and community members as partners in character building efforts; (11) evaluating the character of the school, the function of the school staff as character educators, and the extent to which students manifest good character (Glanzer \& Milson, 2006; Waryandani \& Ambarwati, 2016: 208-216; Leasa \& Batlolona, 2017: 75-76).

To evaluate the character education success, of course, it cannot be assessed by formative or summative tests expressed in the score. But the benchmark of successful character education is the formation of learners with character; morally, culturally, politely, religiously, creatively, innovatively, independently applied to life throughout his life. Therefore, there is no proper evaluation tool and can instantly demonstrate the success of character education, except good behavior, value, ethics, morals and any ideal behavior that becomes the norm and agreement with society and ideal values implied by the Qur'an and Sunnah that appear spontaneously from each of the learners themselves. Al-Ghazali asserted, "Morals are an attitude that is rooted in the soul from which the birth of various deeds easily and easily without the need for thought and consideration"(Rusn \& Kamdani, 1998).

Teachers as education staff play a substantial role. They not only teach or transfer of knowledge (cognitive) but also provide guidance and training. One of them is to develop these character values in the Learning Implementation Plan (Dewi, 2018).

Furthermore, character education development and its implementation simulation can refer to the formula proposed by (Budiman, 2017), as shown in Figure 1.

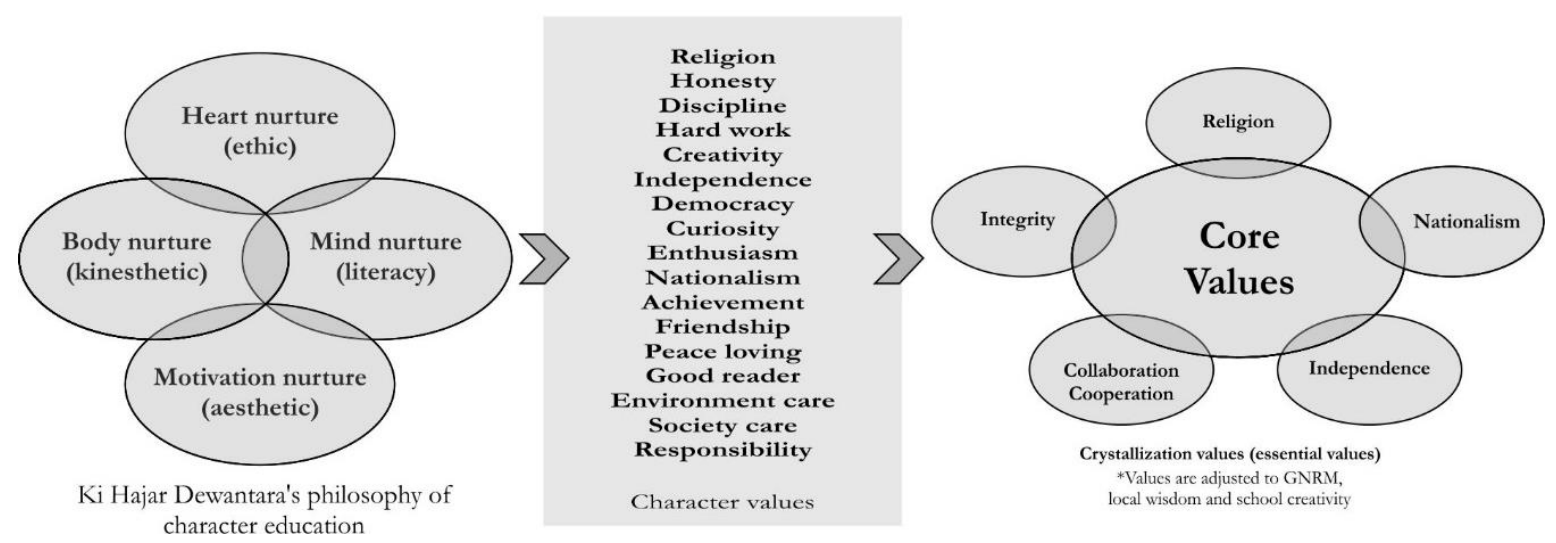

Figure 1. Character Values Development 2013

The strengthening of character education can be carried out through co-curricular and extracurricular activities and habituations that are adapted to school conditions by involving parents and fellow environment, (Budiman, 2017) as shown in Table 1. 
Table 1. Simulation for Strengthening Character Education

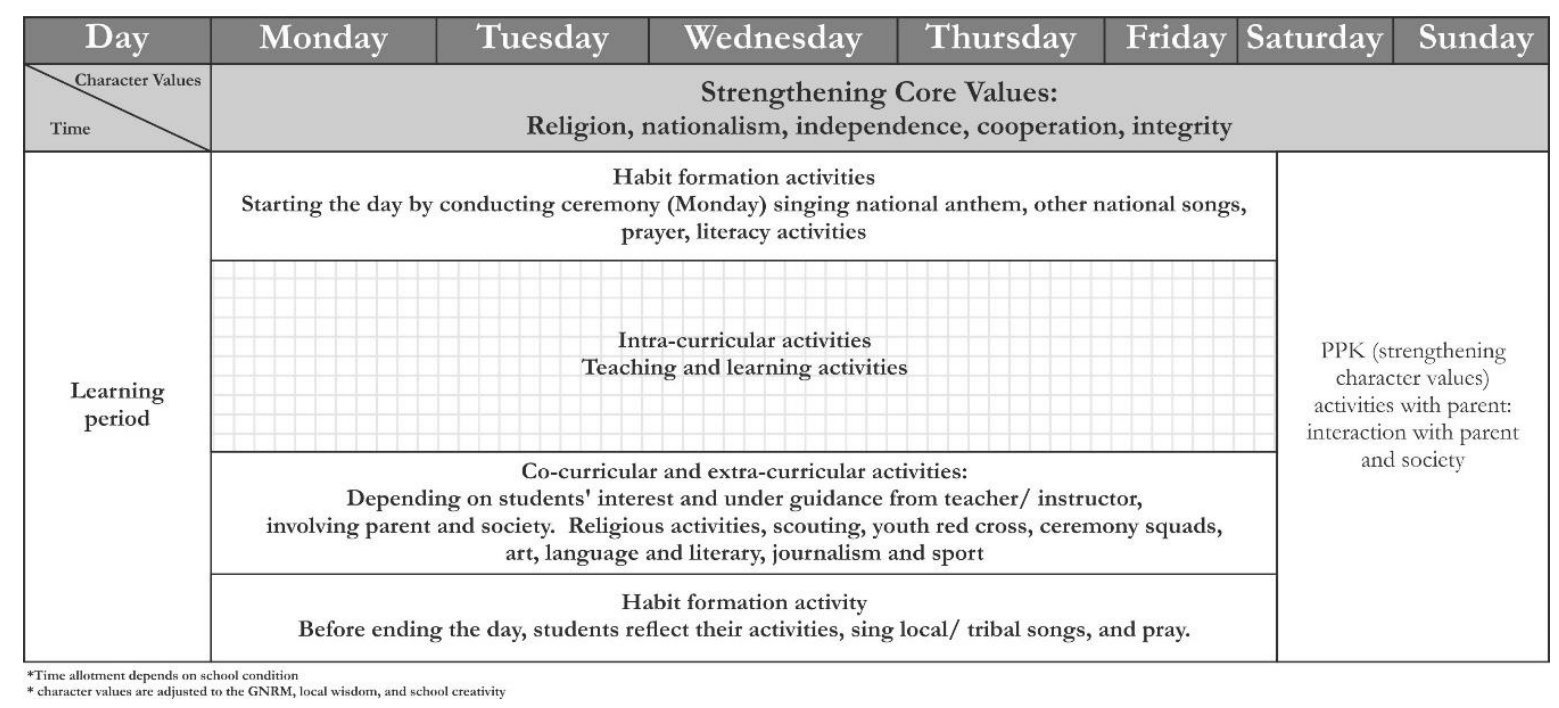

\section{The relevance of the Concept of al-Zarnuji with the Curriculum 2013}

To analyze the relevance of al-Zarnuji's character education concept with a contemporary context, this study takes and compare it with the concept of strengthening character education which becomes a trending topic of curriculum 2013, besides using 11 indicators of character education success as its analysis base.

1. The concept of strengthening character education of curriculum 2013

The concept of strengthening character education of curriculum 2013 consists of:

a. The background of the concept of character education

As revealed at the beginning of the writing, the concept of character education in the Indonesian-speaking discourse arises with regard to the phenomenon of moral decadence occurring in the midst of society. Various criminals and character ailments are increasingly evolving along with technological advances and foreign cultural hegemony. Although the socio-cultural conditions of al-Zarnuji's life are different from the conditions of Indonesian society, they are both linked to an idea program that addresses the moral crisis through education. The difference is that the concept of al-Zarnuji is motivated by his anxiety towards the diligent science but cannot reap the benefits of his fruit and away from the happiness of life. The period he lived was a glorious era of Islamic civilization in general and Islamic education in particular, where the role of philosophy is very dominant. While character education in the curriculum 2013 more motivated by the issue of the crisis of morality and nationalism crisis that is felt increasingly undermining the public in general and the younger generation in particular.

b. Object

The object of the implementation of character education of al-Zarnuji and the government of Indonesia are learners in particular, and society in general. Especially teachers, parents, clerics, stakeholders, and the environment that contribute directly or not to the cultivation of values and morality to learners.

c. Content

Although specifically, the book Ta'lim al-Muta'alim talks about the method of learning but actually discusses learning objectives, principles of learning, learning strategies and so on are always built on the spiritual foundation. Therefore, the dominance of the taste (ethics), the thought (literal) and the aesthetic (aesthetic) are very subtle in the concept. While the education character of the 2013 curriculum includes the aspect of sport (kinesthetic) and the formation of the soul of nationalism as the achievement of character education perfection. 


\section{d. Implementation}

Both al-Zarnuji and Curriculum 2013 view that the implementation of character education is absolutely related to aspects of education, learning, and habituation to learners from an early age. Its success is a joint work between teachers, parents, communities, stakeholders, and learners themselves, both in formal, informal and non-formal education environments.

e. Execution time

Al-Zarnuji saw that education lasted throughout human life from cradle to grave. Likewise, with moral education. While the 2013 curriculum provides a limit to the achievement of this program until 2045 where the formation of Gold Generation is ready to face the dynamics of future changes with 21 st-century skills built on the platform value and character

\section{f. Assessment size}

Both concepts see that the practice of spontaneous character values in daily life is the ultimate goal of its implementation. Therefore, summative and formative tests are not the right instruments to judge.

Pamungkas (2012) states, "an act can be categorized as moral if it meets two criteria: First, Repeated or continuous. If done only once or rarely then it cannot be called morals. If someone suddenly rewards others for some reason, then that person cannot be said to be a generous and noble person. Second, self-motivated, without thinking or weighing because it has become a habit for him. If an action is done afterthought especially because it is forced, then the act is not a character.

2. The concept of al-Zarnuji in terms of Principles of Comprehensive Character Education

The concept of al-Zarnuji when viewed from the Comprehensive Character Education Principles based on the indicators of Glanzer \& Milson, has fulfilled all the elements in question, namely the active involvement of all the learning community both teachers, students, parents (stakeholders), and the school environment (Pebriyenni, 2017), as shown in Table 2.

Table 2. Comprehensive Character Principle

\begin{tabular}{llcl}
\hline No. & \multicolumn{1}{c}{ Comprehensive Character Principle } & \multicolumn{2}{c}{ Al-Zarnuji } \\
\cline { 2 - 3 } Yes & \multicolumn{1}{c}{ No } \\
\hline 1 & Promoting core ethical values as the basis of good character & $\sqrt{ }$ & \\
\hline 2 & $\begin{array}{l}\text { Defining character comprehensively by including thinking, feeling, and } \\
\text { behavior }\end{array}$ & $\sqrt{ }$ & $\sqrt{ }$ \\
\hline 3 & $\begin{array}{l}\text { Using a comprehensive, proactive and effective approach to character } \\
\text { development }\end{array}$ & $\sqrt{ }$ \\
\hline 4 & Creating environmental awareness of school & $\sqrt{ }$ \\
\hline 5 & Providing students with opportunities for moral action & $\sqrt{ }$ \\
\hline 6 & $\begin{array}{l}\text { Including a meaningful and challenging academic curriculum and } \\
\text { respect all learners }\end{array}$ & $\sqrt{ }$ \\
\hline 7 & Trying to encourage student motivation & $\begin{array}{l}\text { Involving school staff in learning and responsible moral communities in } \\
\text { character education and efforts to adhere to the same core values in } \\
\text { guiding student education }\end{array}$ \\
\hline 9 & $\begin{array}{l}\text { Fostering mutual moral leadership and support long-term character } \\
\text { building initiatives }\end{array}$ & $\sqrt{ }$ \\
\hline 10 & $\begin{array}{l}\text { Involving family and community members as partners in character } \\
\text { building efforts }\end{array}$ & $\sqrt{ }$ \\
\hline 11 & $\begin{array}{l}\text { Evaluating school character, the function of school staff as the } \\
\text { character of educator, and how far students manifest good character }\end{array}$ & $\sqrt{ }$ \\
\hline
\end{tabular}


3. Development of the Character Values of al-Zarnuji

Furthermore, character education development can refer to the formula proposed by al-Zarnuji. The implementation of the values of the character of al-Zarnuji is the development of Quranic values that lead to the crystallization of integrity, religion, mutual cooperation, and independence as human values in the form of which are the main values of students, (Budiman, 2017) as shown in Figure 2.
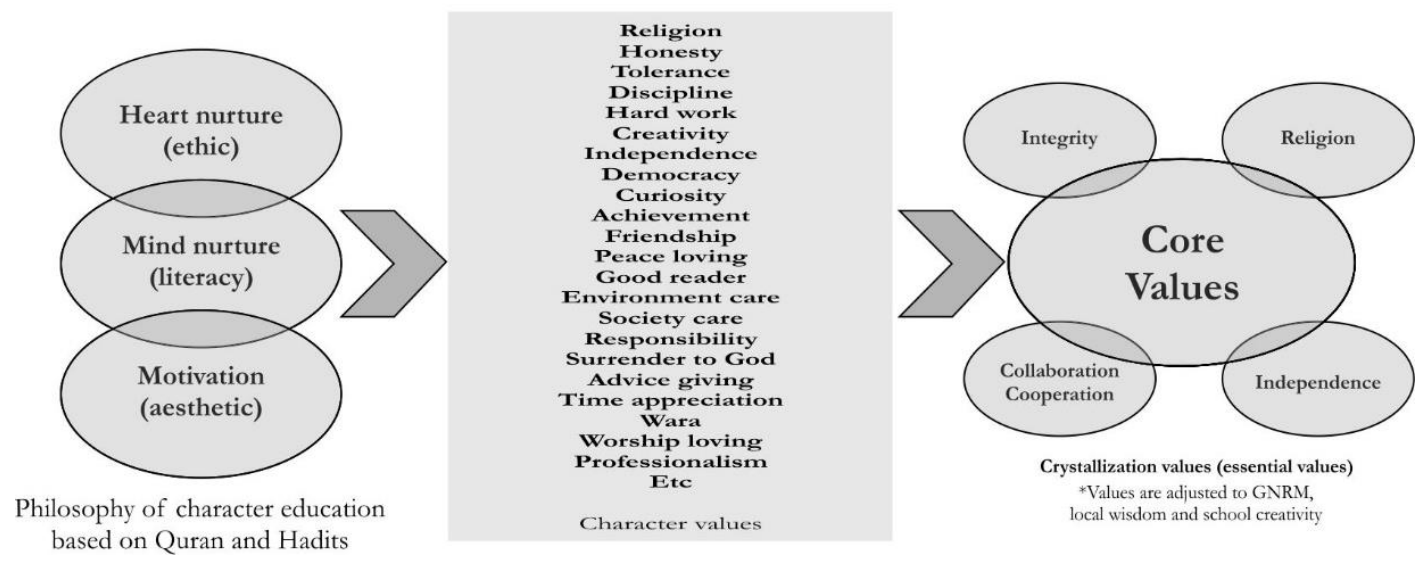

Figure 2. Al-Zarnujzi's Character Values Development

4. PPK (Penguatan Pendidikan Karakter/Strengthening Character Education) Analysis in 13 Article of Ta'lim al-Muta'allim

In this part, 13 articles in book Ta'lim al-Muta'allim will be analyzed deeply through the Strengthening Character Education, as shown in Table 3.

Table 3. Analysis of the Implementation of Character Strengthening in 13 Articles of Ta'lim alMuta'allim

\begin{tabular}{|c|c|c|c|c|c|}
\hline No & $\begin{array}{l}\text { Field of } \\
\text { Educational }\end{array}$ & Character Type & $\begin{array}{l}\text { Attitude / } \\
\text { Domain }\end{array}$ & Value of Character & $\begin{array}{l}\text { Christalization } \\
\text { Values }\end{array}$ \\
\hline \multirow{7}{*}{1} & \multirow{7}{*}{$\begin{array}{l}\text { Science and } \\
\text { virtue learning is } \\
\text { an obligation }\end{array}$} & Learning is everyone's duty & $\begin{array}{l}\text { Spiritual and } \\
\text { knowledge }\end{array}$ & $\begin{array}{l}\text { Empowering heart } \\
\text { and thought }\end{array}$ & Religious and integrity \\
\hline & & $\begin{array}{l}\text { Obligations of every Muslim } \\
\text { studying his religious science }\end{array}$ & $\begin{array}{l}\text { Spiritual and } \\
\text { knowledge }\end{array}$ & $\begin{array}{l}\text { Empowering heart } \\
\text { and thought }\end{array}$ & Religious and integrity \\
\hline & & $\begin{array}{l}\text { The obligation to study the } \\
\text { sciences related to his } \\
\text { profession }\end{array}$ & $\begin{array}{l}\text { Knowledge \& } \\
\text { Skills }\end{array}$ & $\begin{array}{l}\text { Empowering } \\
\text { heart, though, and } \\
\text { skill }\end{array}$ & Independent \\
\hline & & $\begin{array}{l}\text { The obligation to learn good } \\
\text { and bad moral }\end{array}$ & $\begin{array}{l}\text { Spiritual \& } \\
\text { Knowledge }\end{array}$ & $\begin{array}{l}\text { Empowering heart } \\
\text { and thought }\end{array}$ & Religious and integrity \\
\hline & & $\begin{array}{l}\text { Learning the science as fardhu } \\
\text { kifäyah }\end{array}$ & $\begin{array}{l}\text { Spiritual \& } \\
\text { Knowledge }\end{array}$ & $\begin{array}{l}\text { Empowering } \\
\text { heart, thought, and } \\
\text { skill }\end{array}$ & $\begin{array}{l}\text { Independent and } \\
\text { mutual help }\end{array}$ \\
\hline & & $\begin{array}{l}\text { Learning haram and mudlarat } \\
\text { such as astrology }\end{array}$ & $\begin{array}{l}\text { Spiritual \& } \\
\text { Knowledge }\end{array}$ & $\begin{array}{l}\text { Empowering heart } \\
\text { and thought }\end{array}$ & Religious and integrity \\
\hline & & $\begin{array}{l}\text { Figh is the main/important of } \\
\text { science }\end{array}$ & $\begin{array}{l}\text { Spiritual, } \\
\text { knowledge. \& } \\
\text { Skills } \\
\end{array}$ & $\begin{array}{l}\text { Empowering } \\
\text { heart, thought, and } \\
\text { skill }\end{array}$ & Religious and integrity \\
\hline \multirow{3}{*}{2} & \multirow{3}{*}{ Learning intents } & $\begin{array}{l}\text { Learning intentions must be } \\
\text { good and true }\end{array}$ & $\begin{array}{l}\text { Spiritual \& } \\
\text { Knowledge } \\
\end{array}$ & $\begin{array}{l}\text { Empowering heart } \\
\text { and thought }\end{array}$ & Religious and integrity \\
\hline & & $\begin{array}{l}\text { The purpose of the study is } \\
\text { simply to seek the pleasure of } \\
\text { Allah }\end{array}$ & $\begin{array}{l}\text { Spiritual \& } \\
\text { Knowledge }\end{array}$ & $\begin{array}{l}\text { Empowering heart } \\
\text { and thought }\end{array}$ & Religious and integrity \\
\hline & & $\begin{array}{l}\text { The purpose of learning to } \\
\text { achieve the happiness of the } \\
\text { world-the hereafter }\end{array}$ & $\begin{array}{l}\text { Spiritual, } \\
\text { knowledge \& } \\
\text { Skills }\end{array}$ & $\begin{array}{l}\text { Empowering } \\
\text { heart, thought, and } \\
\text { skill }\end{array}$ & $\begin{array}{l}\text { Integrity and } \\
\text { independent }\end{array}$ \\
\hline
\end{tabular}




\begin{tabular}{|c|c|c|c|c|c|}
\hline No & $\begin{array}{l}\text { Field of } \\
\text { Educational }\end{array}$ & Character Type & $\begin{array}{l}\text { Attitude / } \\
\text { Domain }\end{array}$ & Value of Character & $\begin{array}{c}\text { Christalization } \\
\text { Values }\end{array}$ \\
\hline \multirow{5}{*}{3} & \multirow{5}{*}{$\begin{array}{l}\text { Chose teachers } \\
\text { and friends learn }\end{array}$} & $\begin{array}{l}\text { Choosing the best kind of } \\
\text { science and life needed }\end{array}$ & $\begin{array}{l}\text { Spiritual, } \\
\text { knowledge.\& } \\
\text { Skill }\end{array}$ & $\begin{array}{l}\text { Empowering } \\
\text { heart, thought, and } \\
\text { skill }\end{array}$ & $\begin{array}{l}\text { Integrity and } \\
\text { independent }\end{array}$ \\
\hline & & $\begin{array}{l}\text { Preface the science of Taubid } \\
\text { and ma'rifat }\end{array}$ & $\begin{array}{l}\text { Spiritual and } \\
\text { knowledge }\end{array}$ & $\begin{array}{l}\text { Empowering } \\
\text { knowledge and } \\
\text { heart }\end{array}$ & $\begin{array}{l}\text { Integrity and } \\
\text { independent }\end{array}$ \\
\hline & & $\begin{array}{l}\text { Prioritize wara', pious and } \\
\text { patient educators }\end{array}$ & $\begin{array}{l}\text { Spiritual and } \\
\text { knowledge }\end{array}$ & $\begin{array}{l}\text { Empowering heart } \\
\text { and thought }\end{array}$ & Religious and integrity \\
\hline & & $\begin{array}{l}\text { Choosing friends who wara', } \\
\text { honest and easy to } \\
\text { understand the problem }\end{array}$ & $\begin{array}{l}\text { Spiritual and } \\
\text { knowledge }\end{array}$ & $\begin{array}{l}\text { Empowering } \\
\text { heart, thought, and } \\
\text { skill }\end{array}$ & $\begin{array}{l}\text { Integrity and } \\
\text { independent }\end{array}$ \\
\hline & & $\begin{array}{l}\text { No friends with lazy, } \\
\text { talkative, unemployed \& } \\
\text { libelous }\end{array}$ & $\begin{array}{l}\text { Spiritual and } \\
\text { Knowledge }\end{array}$ & $\begin{array}{l}\text { Empowering heart } \\
\text { thought and skill }\end{array}$ & $\begin{array}{l}\text { Integrity and } \\
\text { independent }\end{array}$ \\
\hline \multirow{3}{*}{4} & \multirow{3}{*}{$\begin{array}{l}\text { Respect science } \\
\text { and scholars }\end{array}$} & Seriously in learning & $\begin{array}{l}\text { Spiritual and } \\
\text { knowledge }\end{array}$ & $\begin{array}{l}\text { Empowering heart } \\
\text { and thought }\end{array}$ & $\begin{array}{l}\text { Integrity and } \\
\text { independent }\end{array}$ \\
\hline & & $\begin{array}{l}\text { Have a strong interest in } \\
\text { learning }\end{array}$ & $\begin{array}{l}\text { Spiritual and } \\
\text { knowledge }\end{array}$ & $\begin{array}{l}\text { Empowering heart } \\
\text { and thought }\end{array}$ & $\begin{array}{l}\text { Integrity and } \\
\text { independent }\end{array}$ \\
\hline & & $\begin{array}{l}\text { Putting forward the principle } \\
\text { of continuity in learning }\end{array}$ & $\begin{array}{l}\text { Knowledge.\& } \\
\text { Skills }\end{array}$ & $\begin{array}{l}\text { Empowering heart } \\
\text { and thought }\end{array}$ & Integrity \\
\hline \multirow{2}{*}{5} & \multirow{2}{*}{$\begin{array}{l}\text { Sincere, } \\
\text { continuity, strong } \\
\text { interest }\end{array}$} & $\begin{array}{l}\text { Continuing learning } \\
\text { sustainability }\end{array}$ & $\begin{array}{l}\text { Knowledge \& } \\
\text { Skills }\end{array}$ & $\begin{array}{l}\text { Empowering } \\
\text { thought and skill }\end{array}$ & $\begin{array}{l}\text { Integrity and } \\
\text { independent }\end{array}$ \\
\hline & & $\begin{array}{l}\text { Not doing activities that make } \\
\text { tired and not useful }\end{array}$ & $\begin{array}{l}\text { Knowledge \& } \\
\text { Skills } \\
\end{array}$ & $\begin{array}{l}\text { Empowering } \\
\text { thought and skill }\end{array}$ & $\begin{array}{l}\text { Integrity and } \\
\text { independent }\end{array}$ \\
\hline \multirow{4}{*}{6} & \multirow{4}{*}{$\begin{array}{l}\text { Beginning with } \\
\text { learning, level, } \\
\text { and sequence }\end{array}$} & $\begin{array}{l}\text { Wednesday is the best day to } \\
\text { start learning }\end{array}$ & $\begin{array}{l}\text { Spiritual and } \\
\text { knowledge }\end{array}$ & $\begin{array}{l}\text { Empowering heart } \\
\text { and thought }\end{array}$ & Religious \\
\hline & & $\begin{array}{l}\text { Learning is done little by little } \\
\text { (Tadarruj) }\end{array}$ & $\begin{array}{l}\text { Spiritual and } \\
\text { knowledge }\end{array}$ & $\begin{array}{l}\text { Empowering } \\
\text { thought and skill }\end{array}$ & $\begin{array}{l}\text { Integrity and } \\
\text { independent }\end{array}$ \\
\hline & & $\begin{array}{l}\text { Learning must be repeated } \\
\text { (repetition) }\end{array}$ & $\begin{array}{l}\text { Knowledge and } \\
\text { Skill }\end{array}$ & $\begin{array}{l}\text { Empowering } \\
\text { thought and skill }\end{array}$ & $\begin{array}{l}\text { Integrity and } \\
\text { independent }\end{array}$ \\
\hline & & $\begin{array}{l}\text { Students should be happy to } \\
\text { buy and have books (kitab) }\end{array}$ & $\begin{array}{l}\text { Knowledge and } \\
\text { Skill }\end{array}$ & $\begin{array}{l}\text { Empowering } \\
\text { thought and skill }\end{array}$ & $\begin{array}{l}\text { Integrity and } \\
\text { independent }\end{array}$ \\
\hline \multirow{3}{*}{7} & \multirow{3}{*}{ Tawakkal } & $\begin{array}{l}\text { Familiarize tawakkal as the } \\
\text { pattern life }\end{array}$ & $\begin{array}{l}\text { Spiritual and } \\
\text { knowledge }\end{array}$ & $\begin{array}{l}\text { Empowering heart } \\
\text { and thought }\end{array}$ & Religious and integrity \\
\hline & & $\begin{array}{l}\text { Not tempted the affairs of } \\
\text { sustenance and worldly }\end{array}$ & $\begin{array}{l}\text { Spiritual and } \\
\text { knowledge }\end{array}$ & $\begin{array}{l}\text { Empowering heart } \\
\text { and thought }\end{array}$ & Religious and integrity \\
\hline & & Must multiply patience & $\begin{array}{l}\text { Spiritual, } \\
\text { knowledge.\& Skill }\end{array}$ & $\begin{array}{l}\text { Empowering heart } \\
\text { and thought }\end{array}$ & $\begin{array}{l}\text { Integrity and } \\
\text { independent }\end{array}$ \\
\hline \multirow{5}{*}{8} & \multirow{5}{*}{$\begin{array}{l}\text { The Best Time to } \\
\text { Learn }\end{array}$} & $\begin{array}{l}\text { Learning strived from the } \\
\text { cradle to the grave }\end{array}$ & $\begin{array}{l}\text { Spiritual and } \\
\text { knowledge }\end{array}$ & $\begin{array}{l}\text { Empowering heart } \\
\text { and thought }\end{array}$ & Religious and integrity \\
\hline & & $\begin{array}{l}\text { Youth is the most brilliant } \\
\text { time to learn }\end{array}$ & $\begin{array}{l}\text { Spiritual, } \\
\text { knowledge.\& } \\
\text { Skill } \\
\end{array}$ & $\begin{array}{l}\text { Empowering } \\
\text { thought and skill }\end{array}$ & $\begin{array}{l}\text { Integrity and } \\
\text { independent }\end{array}$ \\
\hline & & $\begin{array}{l}\text { The most appropriate time to } \\
\text { learn is the time of dawn and } \\
\text { between Maghrib and 'Isha }\end{array}$ & $\begin{array}{l}\text { Spiritual, } \\
\text { knowledge.\& } \\
\text { Skill } \\
\end{array}$ & $\begin{array}{l}\text { Empowering } \\
\text { heart, though, and } \\
\text { skill }\end{array}$ & $\begin{array}{l}\text { Integrity and } \\
\text { independent }\end{array}$ \\
\hline & & $\begin{array}{l}\text { Utilize all the time for } \\
\text { learning }\end{array}$ & $\begin{array}{l}\text { Spiritual, } \\
\text { knowledge.\& } \\
\text { Skill } \\
\end{array}$ & $\begin{array}{l}\text { Empowering } \\
\text { heart, though, and } \\
\text { skill }\end{array}$ & $\begin{array}{l}\text { Integrity and } \\
\text { independent }\end{array}$ \\
\hline & & $\begin{array}{l}\text { If tired of learning science } \\
\text { should move to another } \\
\text { science }\end{array}$ & $\begin{array}{l}\text { Knowledge and } \\
\text { Skill }\end{array}$ & $\begin{array}{l}\text { Empowering } \\
\text { heart, though, and } \\
\text { skill }\end{array}$ & $\begin{array}{l}\text { Integrity and } \\
\text { independent }\end{array}$ \\
\hline \multirow{6}{*}{9} & \multirow{6}{*}{$\begin{array}{l}\text { Affection and } \\
\text { advice }\end{array}$} & Have a loving nature & Spiritual & Empowering heart & Religious and integrity \\
\hline & & Likes giving advice & Spiritual & Empowering heart & Religious and integrity \\
\hline & & Not Spiteful & Spiritual & Empowering heart & Religious and integrity \\
\hline & & $\begin{array}{l}\text { Adorn yourself with akbläk } \\
\text { karimah }\end{array}$ & Spiritual & Empowering heart & $\begin{array}{l}\text { Religious, integrity, } \\
\text { and independent }\end{array}$ \\
\hline & & Not worse suspect & Spiritual & Empowering heart & Religious and integrity \\
\hline & & $\begin{array}{l}\text { Do not involve yourself in } \\
\text { hostility }\end{array}$ & Spiritual & Empowering heart & $\begin{array}{l}\text { Integrity and } \\
\text { independent }\end{array}$ \\
\hline
\end{tabular}




\begin{tabular}{|c|c|c|c|c|c|}
\hline No & $\begin{array}{l}\text { Field of } \\
\text { Educational }\end{array}$ & Character Type & $\begin{array}{l}\text { Attitude / } \\
\text { Domain }\end{array}$ & Value of Character & Christalization Values \\
\hline \multirow{6}{*}{10} & \multirow{6}{*}{$\begin{array}{l}\text { Take advantage } \\
\text { of the time }\end{array}$} & $\begin{array}{l}\text { Take advantage of all } \\
\text { opportunities to learn }\end{array}$ & $\begin{array}{l}\text { Knowledge and } \\
\text { skill }\end{array}$ & $\begin{array}{l}\text { Empowering } \\
\text { thought and skill }\end{array}$ & $\begin{array}{l}\text { Integrity and } \\
\text { independent }\end{array}$ \\
\hline & & Provide stationery at all times & $\begin{array}{l}\text { Knowledge and } \\
\text { skill }\end{array}$ & $\begin{array}{l}\text { Empowering } \\
\text { thought and skill }\end{array}$ & $\begin{array}{l}\text { Integrity and } \\
\text { independent }\end{array}$ \\
\hline & & $\begin{array}{l}\text { Record the scientific things } \\
\text { that he acquired }\end{array}$ & $\begin{array}{l}\text { Knowledge and } \\
\text { skill }\end{array}$ & $\begin{array}{l}\text { Empowering } \\
\text { thought and skill }\end{array}$ & Independent \\
\hline & & $\begin{array}{l}\text { Make use of the night time } \\
\text { and in the quiet time to learn }\end{array}$ & $\begin{array}{l}\text { Spiritual, } \\
\text { knowledge, and } \\
\text { skill }\end{array}$ & $\begin{array}{l}\text { Empowering heart, } \\
\text { though, and skill }\end{array}$ & $\begin{array}{l}\text { Religious, integrity, } \\
\text { and independent }\end{array}$ \\
\hline & & Dare to suffer & $\begin{array}{l}\text { Knowledge and } \\
\text { skill }\end{array}$ & $\begin{array}{l}\text { Empowering } \\
\text { thought and skill }\end{array}$ & $\begin{array}{l}\text { Integrity and } \\
\text { independent }\end{array}$ \\
\hline & & Able to subdue lust & Spiritual & $\begin{array}{l}\text { Empowering } \\
\text { thought and skill }\end{array}$ & $\begin{array}{l}\text { Religious, integrity, } \\
\text { and independent }\end{array}$ \\
\hline \multirow{9}{*}{11} & \multirow{9}{*}{ Wara' } & Apply Wara' as a pattern life & Spiritual & Empowering heart & Religious dan integrity \\
\hline & & Not overeating and too full & $\begin{array}{l}\text { Spiritual dan } \\
\text { knowledge }\end{array}$ & $\begin{array}{l}\text { Empowering heart } \\
\text { and thought }\end{array}$ & Integrity \\
\hline & & Do not multiply sleep & Knowledge & $\begin{array}{l}\text { Empowering } \\
\text { thought }\end{array}$ & Integrity \\
\hline & & $\begin{array}{l}\text { Not much talk about things } \\
\text { that are not useful }\end{array}$ & Knowledge & Empowering heart & Integrity \\
\hline & & Keeping adab courtesy & Spiritual & Empowering heart & $\begin{array}{l}\text { Religious, integrity, } \\
\text { and independent }\end{array}$ \\
\hline & & $\begin{array}{l}\text { Familiarize the actions of } \\
\text { sunnab }\end{array}$ & $\begin{array}{l}\text { Spiritual, and } \\
\text { skill }\end{array}$ & $\begin{array}{l}\text { Empowering } \\
\text { heart, thought, and } \\
\text { skill }\end{array}$ & $\begin{array}{l}\text { Religious, integrity, } \\
\text { and independent }\end{array}$ \\
\hline & & $\begin{array}{l}\text { Increase prayer and execute it } \\
\text { solemnly }\end{array}$ & Spiritual & Empowering heart & $\begin{array}{l}\text { Religious and } \\
\text { independent }\end{array}$ \\
\hline & & $\begin{array}{l}\text { Bring books anywhere to } \\
\text { learn }\end{array}$ & $\begin{array}{l}\text { Knowledge and } \\
\text { skill }\end{array}$ & $\begin{array}{l}\text { Empowering } \\
\text { thought and skill }\end{array}$ & $\begin{array}{l}\text { Integrity and } \\
\text { independent }\end{array}$ \\
\hline & & $\begin{array}{l}\text { Bringing stationery to record } \\
\text { the knowledge gained }\end{array}$ & Skill & $\begin{array}{l}\text { Empowering } \\
\text { thought and skill }\end{array}$ & Independent \\
\hline \multirow{5}{*}{12} & \multirow{5}{*}{$\begin{array}{l}\text { The things that } \\
\text { make learning } \\
\text { memorable easier }\end{array}$} & $\begin{array}{l}\text { Have a strong interest to } \\
\text { memorize Knowledge }\end{array}$ & $\begin{array}{l}\text { Knowledge and } \\
\text { skill }\end{array}$ & $\begin{array}{l}\text { Empowering } \\
\text { thought and skill }\end{array}$ & $\begin{array}{l}\text { Integrity and } \\
\text { independent }\end{array}$ \\
\hline & & Sincere and continuity & $\begin{array}{l}\text { Knowledge and } \\
\text { skill }\end{array}$ & $\begin{array}{l}\text { Empowering } \\
\text { thought and skill }\end{array}$ & $\begin{array}{l}\text { Integrity and } \\
\text { independent }\end{array}$ \\
\hline & & Prayers at night & Spiritual & Empowering heart & $\begin{array}{l}\text { Integrity and } \\
\text { independent }\end{array}$ \\
\hline & & Reproduce read the Qur'an & Spiritual & Empowering heart & $\begin{array}{l}\text { Integrity and } \\
\text { independent }\end{array}$ \\
\hline & & Reduce a lot of eating & Knowledge & $\begin{array}{l}\text { Empowering } \\
\text { thought }\end{array}$ & $\begin{array}{l}\text { Integrity and } \\
\text { independent }\end{array}$ \\
\hline \multirow{11}{*}{13} & \multirow{11}{*}{$\begin{array}{l}\text { Sustenance and } \\
\text { Age }\end{array}$} & Wake up in the morning & Knowledge & $\begin{array}{l}\text { Empowering } \\
\text { thought }\end{array}$ & $\begin{array}{l}\text { Integrity and } \\
\text { independent }\end{array}$ \\
\hline & & A lot of charity & Spiritual & Empowering heart & $\begin{array}{l}\text { Religious, integrity, } \\
\text { and independent }\end{array}$ \\
\hline & & $\begin{array}{l}\text { Prayers with } t a^{\prime} d \text { qim }^{\mathrm{m}} \text {, solemn and } \\
\text { perfectly harmonious, } \\
\text { compulsory, sunnab and the ruler }\end{array}$ & $\begin{array}{l}\text { Spiritual, } \\
\text { knowledge }\end{array}$ & Empowering heart & $\begin{array}{l}\text { Religious, integrity, } \\
\text { and independent }\end{array}$ \\
\hline & & Doing good deeds & Spiritual & Empowering heart & Religious and integrity \\
\hline & & Does not hurt others & Spiritual & Empowering heart & Integrity \\
\hline & & Increase silaturrahim & $\begin{array}{l}\text { Spiritual and } \\
\text { skill }\end{array}$ & $\begin{array}{l}\text { Empowering heart } \\
\text { and skill }\end{array}$ & $\begin{array}{l}\text { Religious, integrity, } \\
\text { and independent }\end{array}$ \\
\hline & & Do not squander the treasures & $\begin{array}{l}\text { Spiritual and } \\
\text { skill }\end{array}$ & $\begin{array}{l}\text { Empowering heart } \\
\text { and skill }\end{array}$ & $\begin{array}{l}\text { Integrity and } \\
\text { independent }\end{array}$ \\
\hline & & No lazy & knowledge & $\begin{array}{l}\text { Empowering } \\
\text { thought }\end{array}$ & $\begin{array}{l}\text { Integrity and } \\
\text { independent }\end{array}$ \\
\hline & & Do not procrastinate & knowledge & Empowering thought & $\begin{array}{l}\text { Integrity and } \\
\text { independent }\end{array}$ \\
\hline & & Do not underestimate & knowledge & Empowering thought & $\begin{array}{l}\text { Integrity and } \\
\text { independence }\end{array}$ \\
\hline & & Learn the science of health & knowledge & $\begin{array}{l}\text { Empowering } \\
\text { thought, skill, and } \\
\text { sports }\end{array}$ & $\begin{array}{l}\text { Integrity and } \\
\text { independent }\end{array}$ \\
\hline
\end{tabular}


From Table 3, it is clear that almost all the concepts of al-Zarnuji's character education contained in the book Ta'lim al-Muta'allim have similarities with the concept of strengthening the education of the curriculum character of 2013. Both are moving in the same direction towards the formation of a plenary generation capable of implementing the value- moral values/morals in everyday life.

Character development in the curriculum 2013 adopts Ki Hajar Dewantara's character education philosophy, with the construction of the heart, though, skill and sports, while the concept of al-Zarnuji's character education prefers the heart, thought and esthetic. In plain view, it seems as though al-Zarnuji neglected the aspect of skill (kinesthetic), but if analyzed more deeply, that aspect has been implied in the suggestion of chapter 13 (sustenance and age) about the suggestion of studying health science. Likewise, on the contrary, character education in the 2013 curriculum is adopted from Ki Hajar Dewantara's character education philosophy. Ki Hajar Dewantara was also in accordance with the spirit of al-Qur'an and Sunnah. The prophet ever encouraged his people to be disciplined and exercise. The Messenger of Allah said, "Teach your children to ride, swim and shoot" (Bukhari/Muslim).

\section{CONCLUSION}

The concept of al-Zarnuji's character education has been written in a structured book called Ta'lim al-Mutallim. In essence, the concept of al-Zarnuji's character education not only makes the learners as a target of shoot but also touches the various lines of life, levels, and layers of society, ranging from educators, parents, learners, the environment, customs and habits of a person who affect the character, character, and character of a person. The process of character or moral formation that takes place continuously as a habit of life between teachers and students in the moral interaction of being through learning and daily life behavior.

The construction of al-Zarnuji's character education is the implementation of the qur'anic and hadith values as the standard of morality and the foundation for the implementation of teaching and learning activities. Because it stands on the right foundation (al-Qur'an and Hadith), the concept of character educational of al-Zarnuji remains relevant and updated throughout the ages. Although some of the text of his book is no longer contextual to the present size, especially with regard to the technical aspects of what is allowed and prohibited for learners, most of the suggestions, if analyzed more closely, there is the essence of goodness that is contained in it, and perhaps our analysis knife or scientific knowledge about it has not been revealed to date.

It can be concluded that almost all the concept of al-Zarnuji's character education contained in the book of Ta'lim al-Muta'allim have similarities with the concept of Strengthening Character Education (PPK) Curriculum 2013. Both are moving in the direction of forming a plenary generation capable of implementing moral values/morality that Qur'anic and Pancasila in everyday life to welcome the presence of the golden generation in the future.

\section{BIBLIOGRAPHY}

Al-Baghdādī, A. B. A. A. K., \& `Azazi, A. A. R. A. Y. (2001). Kitab al-faqih wa-al-mutafaqqih. Dar Ibn al-Jawzy. Retrieved from https://books.google.co.id/ books?id= OUZzAQAACAAJ

Albani, S. A. (310). Hadits shabih.

Al-Ghazali. (2011). Ibya' 'ulumuddin: Menghidupkan ilmu-ilmu agama Islam. MARJA. Retrieved from https://books.google.co.id/books?id=t9lUAQAACAAJ

Al-Kinani, A. Q. I. (2009). Permata Salaf. Darul Kutub Al-Ilmiyyah.

Al-Zarnuzi, B. (n.d.). Al-Risalah al-Ta'lim al Muta'allim. Beirut: Al-Risalah al-Ta'lim al Muta'allim. 
Budiman, A. (2017). Pengembangan nilai-nilai karakter kurikulum 2013. Jakarta: Kementrian Pendidikan dan Kebudayan RI.

Chomaidi. (2005). Peranan pendidikan dalam upaya meningkatkan sumber daya manusia. Yogyakarta: UNY.

Chotimah. (2018). Relevansi konsep pendidikan karakter menurut syekh Burhanuddin al-Zarnuji dalam kitab Ta'lim Muta'allim dengan kurikulum 2013. Jakarta: Bebook Publisher.

Dewi, N. N. S. (2018). Analisis pengaruh tingkat persepsi kurikulum 2013 (k13) terhadap kinerja guru PKN pada tingkat satuan pendidikan SD-SMA di UPT dinas pendidikan wilayah Denpasar timur. MAGISTRA: Jurnal Ilmu Manajemen, 2(1), 53-72.

Glanzer, P. L., \& Milson, A. J. (2006). Legislating the good: a survey and evaluation of character education laws in the United States. Educational Policy, 20(3), 525-550. https://doi.org/10.1177/0895904805284115

Hafidzah, L. (2014). Textbooks of Islamic education in Indonesia's traditional pesantren: the use of Al-Zarnuji's ta'lim al-muta'allim tariq at-ta'alum and Hasyim Asy'ari's adab al-âlim wa al-muta'alim. Al-Albab, 3(2). Retrieved from http://jurnaliainpontianak.or.id/index.php/alalbab/article/view/239

Huda, M., \& Jasmi, K. A. (2016). Philosophical investigation of al- Zarnūjī'sTa'līm alMuta'allim: Strengthening ethical engagement into teaching and learning. The Social Sciences, 11(22), 5516-5519. https://doi.org/10.3923/sscience.2016.5516.5519

Huda, M., \& Kartanegara, M. (2015). Aim formulation of education: An analysis of the book Ta'līm al Muta' Allim. International Journal of Humanities and Social Science, 5(2), 143-149.

Kemendiknas. (2010). Nilai-nilai dalam pendidikan karakter bangsa.

Leasa, M., \& Batlolona, J. R. (2017). Full day school dalam pembentukan karakter siswa SMKN 13 kota Malang. Jumal Ilmu Sosial dan Humaniora, 6.

Lickona, T. (2009). Educating for character: How our schools can teach respect and responsibility. Bantam. Retrieved from https://bit.ly/2QUeL69

Mahfud. (2001). Pengantarpsikologi pendidikan. Surabaya: PT. Bina Ilmu.

Masamah, U., \& Zamhari, M. (2017). Relevansi metode pembentukan pendidikan karakter dalam kitab Ta'lim al-Muta'allim terhadap dunia pendidikan modern. Edukasia: Jurnal Penelitian Pendidikan Islam, 11(2), 421-442. https://doi.org/10.21043/edukasia.v11i2.1724

Maslani, M., Suntiah, R., Yasniwarti, Y., \& Nurulhaq, D. (2017). Al-zarnuji's thought of education and its implementation at pesantren. Jurnal Pendidikan Islam, 3(2), 179. https://doi.org/10.15575/jpi.v3i2.1312

Palmer-Cooper, J. A., \& Assifa, F. (2003). 50 pemikirpendidikan: Dari Piaget sampai masa sekarang. Jendela. Retrieved from https://books.google.co.id/books?id=AlF0nQAACAAJ

Pamungkas, M. I. (2012). Akhlak muslim modern: Membangun karakter generasi muda, 8(1). Retrieved from http://journal.uniga.ac.id/index.php/JP/article/view/70

Pebriyenni. (2017). Peran pendidikan kewarganegaraan dalam memperkuat karakter bangsa, 12(2). Retrieved from https: //ejournal.unri.ac.id/index.php/ JPB/article /view/4689/4451

Penders, C. L. M. (1968). Colonial education policy and practice in Indonesia: 1900-1942. Australian National University., Brisbane. Retrieved from https://openresearchrepository.anu.edu.au/handle/1885/132657

Pimay, A. (1999). Konsep pendidik dalam Islam (studi komparasi atas pandangan al-Ghozali dan alZarnuji). Tesis Pascasarjana IAIN Walisongo Semarang, Semarang: Perpustakaan ....

Rusn, A. I., \& Kamdani. (1998). Pemikiran al-Ghazali tentang pendidikan. Pustaka Pelajar. 
Setiawan, A. (2014). Prinsip pendidikan karakter dalam islam: studi komparasi pemikiran alGhazali dan Burhanuddin al-Zarnuji. Dinamika Ilmu, 14(1), 1-12. http://dx.doi.org/10.21093/di.v14i1.4

Shofwan, A. M. (2017). Metode belajar menurut Imam Zarnuji: telaah kitab Ta'lim al muta'alim. Briliant: Jurnal Riset dan Konseptual, 2(4), 408-423. https://doi.org/10.28926/briliant.v2i4.96

Syamsirin. (2010). Pendidikan berbasis etika menurut az-zarnuji dalam prespektif kitab ta'lîm al-muta'allìm tarîqa at-ta'alum. At-Ta'dib, 5(1). https://doi.org/10.21111/attadib.v5i1.584

Thohir, M. A., C, A., \& Dardiri, A. (2017). A comparative study on sheikh az-zarnuji thought and idealism in the philosophy of education. Epistemé: Jurnal Pengembangan Ilmu Keislaman, 12(2), 411-433-433. https://doi.org/10.21274/epis.2017.12.2.411-433

Watson, M. (2008). Developmental discipline and moral education. dalam Nucci, L.P., \& Narvaez, D. (penyunting). Handbook of Moral and Character. Retrieved from https://www3.nd.edu/ dnarvaez/documents/Watson2008.pdf

Wuryandari, W., \& Ambarwati, U. (2016). Implementasi pendidikan karakter kemandirian di Muhammadiyah Boarding School. Cakrawala Pendidikan, XXXV (2), 208-216.

Yunus, M. (1990). Pokok-pokok pendidikan dan pengajaran. Jakarta, Indonesia: PT. Hidakarya Agung. 